\title{
KONSEP ISLAM DAN IMAN \\ Analisis Pemikiran Inklusivisme Muhammad Shahrūr
}

\author{
Laila Rohani \\ Dosen IAIN Sumatra Utara \\ Jl. Willem Iskandar Pasar V Medan Estate 20371 Sumatra Utara \\ e-mail: laila_rohani@yahoo.co.id
}

\begin{abstract}
The basic question being answered in this paper is how to construct inclusiveness thinking of Muhammad Shahrür about Islam and Iman (faith) he explore from the Quran? And what are the implications of such thinking. From his depth studies of the Quran, Shahrür believes that salvation is not only belong to one religion or the salvation of Muslims alone but it can also be found in a religion other than Islam. Anyone who surrenders to God believes in the Day of Judgment and doing a good deed, according to Shahrur, referred to as Muslims. It does not distinguish who he was and comes from what kind of formal religion. That is the conclusion found from his thoughts about religious attitudes.
\end{abstract}

\begin{abstract}
Abstrak: Pertanyaan mendasar yang hendak dijawab dalam tulisan ini adalah bagaimana konstruk pemikiran inklusivisme Muhammad Shahrür tentang Islam dan iman yang dieksplorasinya dari al-Quran? Dan apa implikasi dari pemikirannya tersebut. Dari kajianya yang mendalam terhadap al-Quran, Shahrür berkeyakinan bahwa keselamatan tidak hanya milik satu agama atau orang Islam saja tetapi keselamatan itu bisa pula ditemukan di dalam agama selain Islam. Siapa saja yang pasrah kepada Tuhan beriman kepada hari akhir, dan beramal saleh, menurut Shahrür, disebut sebagai seorang Muslim. Ia tidak membedakan siapa orang itu dan berasal dari agama formal apa, demikian kesimpulan yang ditemukan dari buah pikirannya tentang sikap keberagamaan.
\end{abstract}

Keywords: eksklusivisme absolut, relativisme absolut, inklusivisme hegemonik, pluralisme regulatif, pluralisme realistik

\section{A. Pendahuluan}

Tidak dapat dibantah bahwa beberapa ayat al-Quran mengakui tentang adanya titik temu agama-agama, ${ }^{1}$ dimana masing-masing umat ditetapkan sebuah shir'ah (jalan menuju kepada kebenaran) dan minhāj 
(cara atau metode perjalanan menuju kebenaran). Dengan demikian Allah tidak menghendaki adanya kesamaan manusia dalam segala hal (monolitisisme). Adanya perbedaan menjadi motivasi berlomba menuju berbagai kebajikan; dan Allah akan menilai serta menjelaskan berbagai perbedaan yang ada itu. ${ }^{2}$ Salah satu tokoh yang menganut paham inklusif ini adalah Nurcholish Madjid. ${ }^{3}$

Karya Muḥammad Shaḥrūr, yaitu al-Kitāb wa al-Qur'ān: Qirā'ah $M u$ 'àsirah, mencoba mengusung gagasan-gagasan baru dan cerdas liberal mengenai konsep-konsep al-Quran, baik yang berkaitan dengan diskursus teologi, hukum, moral maupun sosial kemasyarakatan. Buku tersebut dapat dikatakan sebagai karya magnum opus dalam surveinya selama lebih kurang 20 tahun (1970-1990) dan mempunyai signifikansi bagi perkembangan metodologi penfsiran al-Quran, khususnya dalam rangka merespon problem-problem kontemporer sekarang ini, seperti masalah-masalah teologi, hukum, gender, politik, HAM, dan pluralisme agama

Pemikiran Shahrūr yang berseberangan (baca: kontroversial) dengan mainstream pemikiran tradisional-konvensional sebelumnya, yang menyebabkan dirinya dituduh sebagai agen zionis, ingkar sunah, dan lain sebagainya. ${ }^{4}$ Tuduhan-tuduhan semacam itu, sebenarnya sangat disayangkan, sebab pemikiran yang digulirkan Shahrūr sebenarnya dimaksudkan untuk memberikan alternatif dari sekian model penfsiran al-Quran yang selama ini dikenal. Namun itulah, "pil pahit" yang harus ditelan Shahrūr, sebab selama ini tampaknya ada kecenderungan dari sebagian orang dalam menyikapi penafsiran kreatif yang dilandasi semangat kehidupan kontemporer kerap divonis sebagai "latah" atau bahkan diberi stigma buruk sebagai pendangkalan agama.

Pertanyaan mendasar yang hendak dijawab dalam tulisan ini adalah bagaimana konstruk pemikiran inklusivisme Shahrūr tentang Islam dan iman, dan apa implikasi dari pemikirannya tersebut. ${ }^{4 a}$ 


\section{B. Mengenal Sikap-sikap Keberagamaan}

Ninian Smart memetakan sikap teologis seorang penganut agama sebagai berikut: Pertama, eksklusivisme absolut. Kelompok ini menyatakan bahwa kebenaran hanya terdapat di dalam agamanya sendiri. Sementara agama lain dianggap tidak benar. Kedua, relativisme absolut. Kelompok ini menyatakan bahwa sistem kepercayaan agama tidak dapat dibandingkan antara yang satu dengan lainnya karena seseorang harus melepas agamanya untuk mendalami agama orang lain. Ketiga, inklusivisme hegemonik. Kelompok ini melihat ada kebenaran di dalam agama lain, namun agamanya yang terbaik. Keempat, pluralisme realistik. Kelompok ini menyatakan bahwa agama merupakan jalan yang berbeda-beda untuk sebuah kebenaran yang sama. Kelima, pluralisme regulatif. Kelompok ini menyatakan bahwa masing-masing agama memiliki kepercayaannya sendiri dan pada akhirnya akan berevolusi ke arah kebenaran bersama. ${ }^{9}$

Dalam penelitian ilmu agama-agama, menurut John Hick, paling tidak ada tiga sikap keberagamaan tersebut, yaitu: eksklusivisme, inklusivisme dan pluralisme. ${ }^{10}$ Berikut ini akan diuraikan ketiga pandangan teologis tersebut, dengan sedikit latar belakang sejarah teologinya, terutama Kristiani, karena agama Kristiani adalah agama yang sangat panjang pengalaman sejarahnya menyangkut dengan isu ini.

Pertama eksklusivisme, yaitu bahwa kebenaran absolut hanya dimiliki suatu agama tertentu secara eksklusif. Klaim ini tidak memberi alternatif lain apa pun. Ia tidak memberikan konsesi sedikit pun dan tidak mengenal kompromi. Ia memandang kebenaran (truth) secara hitam putih. Klaim kebenaran ini secara umum terdapat pada semua agama. Klaim ini dipresentasikan secara demonstratif oleh agamaagama semitik (Yahudi, Kristen dan Islam). Masing-masing agama tersebut mengklaim diri sebagai ruang soteriologis (soteriological space) yang dengannya manusia akan memperoleh keselamatan. Beberapa contoh dari klaim kebenaran dan keunggulan itu adalah: Yahudi melalui konsep "the chosen people", Katolik dengan doktrin "extra ecclesiam nulla sallus"," Kristen dengan doktrin "out side Christianity, no salvation", sementara Islam dengan ayat, "inna al-dina 'inda Allahi al-islam". 
Kedua inklusivisme, merupakan bentuk klaim kebenaran secara lebih longgar. Di satu pihak, inklusivisme masih tetap meyakini bahwa hanya salah satu agama saja yang benar (the truth) secara absolut, tapi di pihak lain, sikap keberagamaan ini mencoba mengakomodasi konsep keselamatan dan transformasinya untuk mencakup seluruh pengikut agama lain. Inklusivisme ini mendapatkan ekspresinya secara lebih artikulatif dalam pemikiran-pemikiran teologis yang dikembangkan oleh para teolog semisal Karl Rahner dengan teori "anonymous Christian" (Kristen anonim), ${ }^{13}$ kemudian didukung oleh Gavin D'Costa, ${ }^{14}$ dan Raimundo Panikkar dengan "the unknown Christ of Hinduism". 15

Dari kalangan Islam sendiri sering dikemukakan misalnya istilah dari seorang filsuf Muslim abad XIV, Ibn Taymiyyah, yang membedakan antara orang-orang dan agama Islam umum (yang non-Muslim par exxellence), dan orang-orang serta agama Islam khusus (Muslim par excellent). Kata Islam itu sendiri diartikan dengan "sikap pasrah kepada Tuhan". ${ }^{16}$

Dalam tafsiran para penganut paham yang disebut "Islam inklusif" ini, mereka menegaskan bahwa sekalipun mengajarkan pandangan hidup yang disebut al-islām (ketundukan dan sikap pasrah) itu tidak berarti bahwa mereka dan kaumnya menyebut secara harfiah agama mereka al-islām dan mereka sendiri sebagai orang-orang Muslim.

Ketiga pluralisme, merupakan sikap keberagamaan yang ditampilkan oleh penganjurnya sebagai sikap keberagamaan yang ramah, humanis, santun, toleran, cerdas, mecerahkan, demokratis dan promising. Hal ini dapat dilihat dari definisi yang diberikan oleh John Hick, sebagai tokoh utamanya, sebagai berikut: “...the term refers to a particular theory of the relation between these traditions, with their different and competing claims. This is the theory that the great world religions constitute variant conceptions and perceptions of, and responses to, the one ultimate, mysterious divine reality." ${ }^{17}$ Penganut paradigma ini percaya bahwa setiap agama mempunyai jalan keselamatannya sendiri menuju kepada Tuhan Yang Esa, karena itu klaim bahwa agama tertentu adalah satu-satunya jalan (sikap eksklusif), atau yang melengkapi dan mengisi jalan yang lain (sikap inklusif) tidak dapat 
diterima. Dengan kata lain, sikap keberagamaan ini menegaskan bahwa agama-agama merupakan jalan keselamatan bagi penganutnya (soteriological ways), tapi paham ini tidak menganggap bahwa tujuan yang ingin dicapai ke depan adalah keseragaman bentuk agama. Dari kalangan pemikir Muslim, Seyyed Hossein $\mathrm{Nasr}^{18}$ dan Frithjof Shcuon dianggap mewakili sikap keberagamaan ini.

\section{Makna Islam dan Iman}

Menurut Shaḥūur, kata Islām dan ìmān mempunyai arti yang berbeda, meskipun ada persinggungan makna. Dalam menggali kedua konsep tersebut, ia menghimpun seluruh ayat yang menyebut dua istilah tersebut dengan segala derivasinya. Ia memulai dengan menganalisis tiga ayat, yakni (1). QS. al-Ahzāb [33]: 35, yang mengindikasikan adanya komunitas al-muslimūn wa al-muslimāt (laki-laki dan perempuan Muslim) dan komunitas al-mu'minūn wa al-mu'mināt (lakilaki dan perempuan mukmin), (2). QS. al-Tahrīm [66]: 5, yang menyebutkan kata muslimat (wanita muslim) yang disifati dengan kata Mu'minat (beriman) dan (3). QS. al-Hujarāt [49]: 14.

Dalam ayat tersebut, Nabi Muhammad saw. menyangkal pernyataan sekelompok Badui yang mengatakan "Kami telah beriman", sebaliknya Nabi menyuruh mereka untuk mengatakan "aslamna”, kami telah berislam. Ini artinya, mereka belum beriman, meskipun telah berislam. Ketiga ayat itu dipahami oleh Shahrūr bahwa komunitas muslimūn-muslimāt berbeda dengan komunitas $M u$ 'minūn-Mu'mināt, dan bahwa keislaman seseorang datang lebih dahulu dibandingkan keimanannya. ${ }^{19}$

Di sini tampak jelas bahwa Shahrür menggunakan metode tartil dengan analisis syntagmatic-paradigmatic yang mengatakan bahwa penyebutan dua istilah (muslim dan mu'min) secara beriringan dengan disisipi partikel waw menunjukkan kedua istilah itu bukan merupakan sinonim, meskipun ada persaingan makna, tetapi memiliki sense (makna) dan referensi yang berbeda. Ini konsistensi Shahrūr bahwa tidak ada taraduf dalam makna suatu kata. Jadi, wawu 'ataf dalam ayat tersebut berfungsi untuk li al-taghyir (membedakan bahwa yang 
pertama berbeda dengan yang kedua). Seperti halnya jika dikatakan : "Jā'a Ali wa 'Umar" ("Ali dan "Umar datang). Artinya, "Ali berbeda dengan 'Umar.

Selanjutnya, kata Isläm atau turunannya ternyata juga diatributkan untuk umat-umat sebelum datangnya Nabi Muhammad, sebagaimana terdapat dalam QS. al-Jinn [72] : 14; QS Ali 'Imrān [3]: 67; QS. Yūsuf [12]: 101; QS al-A'rāf [7]: 126; QS. Yūnus [10]: 90; QS Ali 'Imrān [3]: 52; QS Yūunus [10]: 42-43; dan QS. al-Żāriyāt [51]: 3536. Kata al-muslimūn disandarkan pada komunitas jin, Nabi Ibrahim, Nabi Ya'qub, Nabi Yusuf, tukang sihir Firaun yang ingin menjadi muslim, al-Hawwariyūn, Nabi Nuh, dan juga Nabi Luth As. Bagi :, fenomena itu memberikan indikasi bahwa Islam bukan hanya untuk umat Nabi Muhammad. ${ }^{20}$

Pendapat semacam ini menurut penulis sebenarnya bukan hal yang baru, sebab Nurcholish Madjid sendiri juga berpendapat seperti itu. Yaitu bahwa Islam/muslim tidak harus terikat dalam agama formal yang dibawa oleh Muhammad siapa saja yang mempunyai sikap kepasrahan total kepada Allah, maka dapat disebut sebagai Islam/ muslim. Di sinilah di antara letak inklusivisme dalam beragama itu.

Demikian halnya Isläm atau muslim menurut al-Quran yang dipahami Syahrur. Ia merujuk QS. al-Baqarah [ 2] : 62, 111, dan 126; QS. al-Nisā' [4]: 125; QS. al-Mā'idah [5]: 44; QS. al-Anbiyā' [21]: 108; dan QS. Fuṣṣilat [41]: 33. Dalam ayat tersebut, dapat dipahami bahwa seseorang bisa dinyatakan Islām jika mengikuti agama Allah dengan syarat beriman kepada Allah, beriman kepada Hari Akhir, dan beramal saleh. Jadi, siapa saja yang memiliki ketiga sifat itu, disebut sebagai seorang muslim, tanpa melihat agama formalnya. Apakah dia termasuk pengikut Nabi Muhammad (al-lażina āmanū), pengikut Nabi Musa (alYahūdu), pengikut Nabi Isa (al-Nașarā), atau umat beragama yang lain. Islām dengan pengertian sebagai dìn yang diterima oleh Allah swt. ${ }^{21}$

Berangkat dari penafsiran semacam ini, Shahrūr berkesimpulan bahwa rukun istām itu ada tiga. Yaitu 1) beriman kepada Allah, 2). Beriman kepada hari akhir, dan 3). Beramal saleh, ihsān, dan bahwa 
kebenaran bisa datang dari agama apa pun di dunia serta keselamatan bisa diperoleh oleh setiap pemeluk agama.

Pandangan seperti ini dapat dikategorikan sebagai pandangan seorang muslim inklusif, namun sayang Shahrür tidak menjelaskan bagaimana ia memahami hadis Nabi riwayat Bukhāri ketika ditanya oleh Malaikat Jibril, “Akhbirnī 'an al Isläm?”'Lalu Nabi menyebutkan bahwa Islam itu adalah bersaksi bahwa tidak ada tuhan selain Allah dan Muhammad adalah Rasulullah, melaksanakan salat, berpuasa, berzakat, dan berhaji jika mampu.

Pandangan Shahrūr ini mirip dengan Fazlur Rahman, pemikir Muslim kontemporer ketika bicara tentang ahl al-Kitāb dalam al-Quran, dengan merujuk Q.S. al-Baqarah [2]: 111-112, yang mengkritik umat Yahudi yang mengklaim diri mereka sebagai satu-satunya pemegang kebenaran dan keselamatan, serta menolak pandangan sementara kaum Nasrani yang mengklaim kebenaran dan keselamatan hanya pada diri mereka.

Al-Quran menjawab secara tegas dengan menyatakan bahwa petunjuk dan keselamatan bukanlah milik kaum tertentu, tetapi milik Tuhan. Tak satu kaum pun dapat mengatakan bahwa hanya merekalah yang mendapat petunjuk Tuhan dan hanya mereka yang akan masuk surga, sedangkan yang lain akan masuk neraka karena tidak mendapatkan petunjuk Tuhan.

Kalau klaim eksklusif dari kalangan Yahudi dan Kristen serta permintaan Ibrahim agar anak cucunya diangkat sebagai pemimpin manusia ditolak oleh al-Quran, maka demikian juga Islam tidak berhak mengklaim bahwa hanya dirinyalah yang akan memperoleh keselamatan. Secara berulang-ulang, sesuai dengan penolakan yang tegas terhadap sikap eksklusif ini, al-Quran mengikuti adanya orangorang saleh di dalam kaum-kaum tertentu, yaitu ahl al-Kitāb, seperti Yahudi, Kristen, dan Sabi'in, sebagaimana pengakuan adanya orangorang beriman dalam Islam. ${ }^{22}$ Pengakuan al-Quran itu tercermin dalam QS. al-Baqarah [2]: 60 dan al-Mâ'idah [5]: 69 berikut ini:

"Sesungguhnya orang-orang mukmin, orang-orang Yahudi, orang-orang Nasrani dan orang-orang Sabi'in, siapa saja di antara mereka yang 
benar-benar beriman kepada Allah, hari kemudian dan beramal saleh, mereka akan menerima pahala dari Tuhan mereka, tidak ada kekhawatiran terhadap mereka, dan tidak (pula) mereka bersedih hati."

"Sesungguhnya orang-orang mukmin, orang-orang Yahudi, Sabi' in dan orang-orang Nasrani, siapa saja (di antara mereka) yang benar-benar beriman kepada Allah, hari kemudian dan beramal saleh, maka tidak ada kekhawatiran terhadap mereka dan tidak (pula) mereka bersedih hati."

Secara implisit, dalam hal ini, Shahrūr ingin juga mengatakan bahwa kritikan al-Quran bisa diarahkan pada pengikut umat Muhammad bila mereka melakukan sebagaimana kaum Yahudi dan Nasrani.

\section{E. Penutup}

Nilai-nilai al-Quran yang inklusif yang ditafsirkan oleh Shạ̣rūr sebenarnya merupakan penguat atas beberapa paham yang sama sebelumnya. Ia meniscayakan bahwa keselamatan tidak hanya milik orang Islam saja. Menurutnya keselamatan itu bisa pula dijumpai di dalam agama selain Islam. Tentu saja, ia mendasari pemikirannya tetap pada sumber utama agama Islam (al-Quran dan Hadis Nabi).

Siapa saja yang pasrah kepada Tuhan, menurut Shahrūr, beriman kepada hari akhir, dan beramal saleh disebut sebagai seorang Muslim. Ia tidak membedakan siapa orang itu dan berasal dari agama formal apa. Pendapat Shậurur tentang konsep Islam seperti itu memang cukup rawan jika dikonsumsi oleh orang awam, bisa-bisa ia dituduh membawa ajaran sesat. Namun perlu dicatat bahwa Shahrür tidak pernah meninggalkan ajaran-ajaran yang disyariatkan agama.[]

\section{Catatan Akhir}

${ }^{1}$ QS. Ali ‘Imrāan [3]: 64.

${ }^{2}$ QS. al-Mā'idah [5]: 48.

${ }^{3}$ Dalam salah satu tulisannya Nurcholish Madjid menyatakan, "Jika para penganut agama itu semua mengamalkan dengan sungguh-sungguh ajaran agama mereka, maka Allah menjanjikan hidup penuh kebahagiaan, baik di dunia ini maupun dalam kehidupan sesudah mati nanti di akhirat..." (Lih.: Nurcholish Madjid, Islam Agama Kemanusiaan; Membangun Tradisi dan Visi Baru Islam Indonesia, Jakarta: Paramadina, 2003, h. 93).

TEOLOGIA, Volume 23, Nomor 2, Juli-DeSEMBER 2012 
${ }^{4}$ Ghazi al-Tawbah, " Shahrūr Yulawwi A’naq al-Nuṣụs li Aghrad Ghayr al'Ilmiyah wa al-Taftaqiru ila al-Bara'ah" dalam Majalah al-Mujtama' No. 1302, 26 Mei 1998, h. 56.

${ }^{4 a}$ Dari Redaksi Teologia. Mengenai biografi Shahrūr sengaja tidak kami tampilkan di artikel ini karena sudah diuraikan dalam tulisan Nur Mahmudah, "Jihad Dalam Pandangan Muhammad Shaḥrür."

${ }^{5}$ Ketika tinggal di Moskow Shahrür sempat terpengaruh dengan pemikiranpemikiran Marxisme. Namun, tidak semua pemikiran Marxisme ia terima begitu saja. Ada beberapa hal yang menjadi perhatian khusus Syahrur, salah satu di antaranya adalah keberpihakannya kepada kaum lemah. Hasil wawancara yang penulis kutip dari Dale F. Eickelman dan Sadek J. Sulaiman, Damaskus, 22 Maret 1996.

${ }^{6}$ Peter Clark, The Shahrur Phenomenon, h. 337.

${ }^{7}$ Charles Kurzman [ed.], Liberal Islam: A Source Book, New York: Oxford University Press, 1998, h. 139.

${ }^{8}$ Mahami Munir Muhammad Ṭāhir al-Shawwaf, Tahāfut al-Qirā’ah alMu'ạsirah, Limmasol Cyprus: al-Shawwaf li al-Nashr, 1993, h. 11.

${ }^{9}$ Ninian Smart, "Pluralism", dalam Donald W. Musser dan Joseph L. Price, $A$ New Hand Book of Christian Theology, Nashville: Abingdon Press, 1992, h. 362.

${ }^{10}$ Klasifikasi ini dibuat oleh John Hick. Untuk lebih lengkapnya lih., John Hick, Problems of Religious Pluralism, Houndmills, Basingstoke: The Macmillan Press, 1985, h. 31-37.

${ }^{11}$ Rabbi Louis Jacob, We Have reason to Believe; Some Aspects of Jewish Theology Examined in the Light of Modern Thouhgt, London: Vallentine, Mitchell, t.th., h. 125-137.

${ }^{12}$ Pandangan seperti ini sudah dikenal lama bahkan sejak abad pertama gereja. Pandangan seperti ini juga diperkuat dengan ungkapan: extra ecclesiam nullus propheta (tidak ada nabi di luar gereja). Pandangan-pandangan seperti ini dikukuhkan dalam Konsili Florence 1442.

${ }^{13}$ John Hick, Problems, h. 33.

${ }^{14}$ Gavin D'Costa, "John Hick and Religious Pluralism; Yet Another Revolution" dalam Harold Hewit [ed.], Problems in Philosophy of Religion; Critical Studies of the Work of John Hick, London: Macmillan Press Ltd, 1991, h. 15.

${ }^{15}$ Raimundo Panikkar, The Unknown Christ of Hinduism, London: Darton, Longmann and Todd, 1981.

${ }^{16}$ Nurcholish Madjid, “al-Islam dan Tradisi Agama Ibrahim”, dalam Ensiklopedia Dunia Islam.

${ }^{17}$ John Hick, "Religious Pluralism", dalam Mircea Eliade [ed.], The Encyclopedia of Religion, New York: Macmillan Publishing Company, 1987, Vol. 12, h. 331 . 
${ }^{18}$ Seyyed Hossein Nasr, The Hearth of Islam; Enduring Values of Humanity, New York, NY: Harper San Fransisco, Harper Collins, 2002, h. 43.

${ }^{19}$ Muhammad Shahrūr, al-Istām wa al-İmān: Manzūmāt al-Qiyām, Damaskus: al-Ahali li al Tiba' ah wa al-Nashr wa al-Tawzi, 1996, h. 31.

${ }^{20}$ Ibid., h. 33.

${ }^{21}$ Ibid., h. 37-38.

${ }^{22}$ Fazlur Rahman, Tema-Tema Pokok al-Qur'an, Bandung: Pustaka, 1993, h. 238.

\section{DAFTAR PUSTAKA}

D’Costa, Gavin, "John Hick and Religious Pluralism; Yet Another Revolution" dalam Harold Hewit [ed.], Problems in Philosophy of Religion; Critical Studies of the Work of John Hick, London: Macmillan Press Ltd, 1991.

Hick, John, "Religious Pluralism", dalam Mircea Eliade [ed.], The Encyclopedia of Religion. New York: Macmillan Publishing Company, 1987.

Jacob, Rabbi Louis, We Have reason to Believe; Some Aspects of Jewish Theology Examined in the Light of Modern Thouhgt, London: Vallentine, Mitchell, t.th.

Kurzman, Charles [ed.], Liberal Islam: A Source Book, New York: Oxford University Press, 1998.

Madjid, Nurcholish, Islam Agama Kemanusiaan; Membangun Tradisi dan Visi Baru Islam Indonesia. Jakarta: Paramadina, 2003.

Nasr, Seyyed Hossein, The Hearth of Islam; Enduring Values of Humanity. New York, NY: Harper San Fransisco, Harper Collins, 2002.

Panikkar, Raimundo, The Unknown Christ of Hinduism. London: Longmann and Todd, 1981.

Rahman, Fazlur, Tema-tema Pokok al-Qur'an; Bandung: Pustaka, 1993.

Shahrūr, Muhammad, al-Islām wa al-Īmān: Manzūūāt al-Qiyām, Damaskus: al-Ahāli li al-Ṭibā'ah wa al-Nashr wa al-Tawżi, 1996.

TEOLOGIA, VOLUME 23, NOMOR 2, JULI-DESEMBER 2012 
Shawwaf, Mahami Munir Muhammad Ṭāhir, Tahāfut al-Qirāàh alMu'ạsirah, Limmasol Cyprus: al-Shawwaf li al-Nashr, 1993.

Smart, Ninian, "Pluralism", dalam Donald W. Musser dan Joseph L. Price, A New Hand Book of Christian Theology, Nashville: Abingdon Press, 1992.

Tawbah, Gazi, "Shahrūr Yulawwi A'naq al-Nuṣụs li Aghrad Gayr al'Ilmiyah wa al-Taftaqiru ila al-Barā'ah"' dalam Majalah alMujtama’No. 1302, 26 Mei 1998. 